\title{
DFNB20: a novel locus for autosomal recessive, non-syndromal sensorineural hearing loss maps to chromosome 11q25-qter
}

\author{
L eanne Moynihan ${ }^{1}$, Mark Houseman ${ }^{1}$, Valerie N ewton ${ }^{2}$, R obert M ueller ${ }^{3}$ and Nicholas \\ L ench $^{1}$
}

${ }^{1}$ M olecular M edicine U nit, U niversity of L eeds, St James's U niversity H ospital, L eeds

${ }^{2} \mathrm{C}$ entre for A udiology, University of $\mathrm{M}$ anchester, O xford Road, M anchester

${ }^{3}$ D epartment of Clinical G enetics, St James's U niversity H ospital, L eeds, UK

\begin{abstract}
A utosomal recessive non-syndromal deafness is an extremely heterogeneous condition with at least 19 loci (D FN B 1-19) already described. We have used autozygosity mapping to localise a further novel locus, DFNB20, to chromosome 11q25-qter in a consanguineous family originating from Pakistan. A region of homozygosity was observed in affected individuals spanning the interval D 11S969-qter.
\end{abstract}

Keywords: autosomal recessive; sensorineural deafness; autozygosity mapping; 11q25; DFNB 20

H earing loss represents an important social and medical phenomenon affecting a significant proportion of the population. Prelingual deafness is particularly important since it impedes oral language acquisition. Congenital or childhood-onset deafness affects approximately $1 / 1000$ children with the majority of cases (approx. 70\%) having no associated syndromal features. ${ }^{1} \mathrm{~A}$ genetic cause is responsible in up to $60 \%$ of cases, most of which display an autosomal recessive mode of inheritance. Non-syndromal sensorineural deafness is genetically extremely heterogeneous, and to date 19 autosomal recessive (DFNB 1-19) and 15 autosomal dominant (DFNA 1-15) loci have been reported. ${ }^{2}$ R ecently, studies have shown that approximately $50 \%$ of all recessive deafness is caused by

Correspondence: NJ Lench, Molecular Medicine U nit, Clinical Sciences B uilding, St James's U niversity H ospital, L eeds, LS9 7TF, U K. Tel: (44) 113206 5681; Fax: (44) 113244 4475; E -mail: desnl@stjames.leeds.ac.uk

R eceived 30 December 1997; revised 10 September 1998; accepted 14 September 1998 mutations in the gene for the gap junction protein connexin 26 throughout different populations including families originating from the UK, France, Italy, Spain, Tunisia, Lebanon, Pakistan, Australia and $\mathrm{New}$ Zealand. ${ }^{3,4}$

We recently ascertained a consanguineous Pakistani family segregating a novel autosomal recessive form of histiocytosis with associated features of joint contractures and sensorineural deafness and showed it to be linked to a locus on chromosome $11 q 25 .{ }^{5}$ Therefore, to determine if a novel locus for non-syndromal sensorineural deafness also maps to this region, we tested 35 consanguineous families (segregating nonsyndromal autosomal recessive sensorineural deafness) originating from Pakistan and the Middle East for linkage to 11q25-qter using 16 microsatellite markers from the region. Previous studies in these 35 consanguineous families had failed to detect linkage to any existing DFNB loci.

In all families studied, detailed clinical histories and physical examinations excluded obvious syndromal or 
acquired causes of hearing loss. DNA was prepared from whole blood or buccal samples using a standard non-organic method. Sixteen fluorescently-labelled microsatellite DNA markers from chromosome 11q25-qter spanning cen-D 11S898-D 11S439-qter (Figure 1) were amplified by the polymerase chain
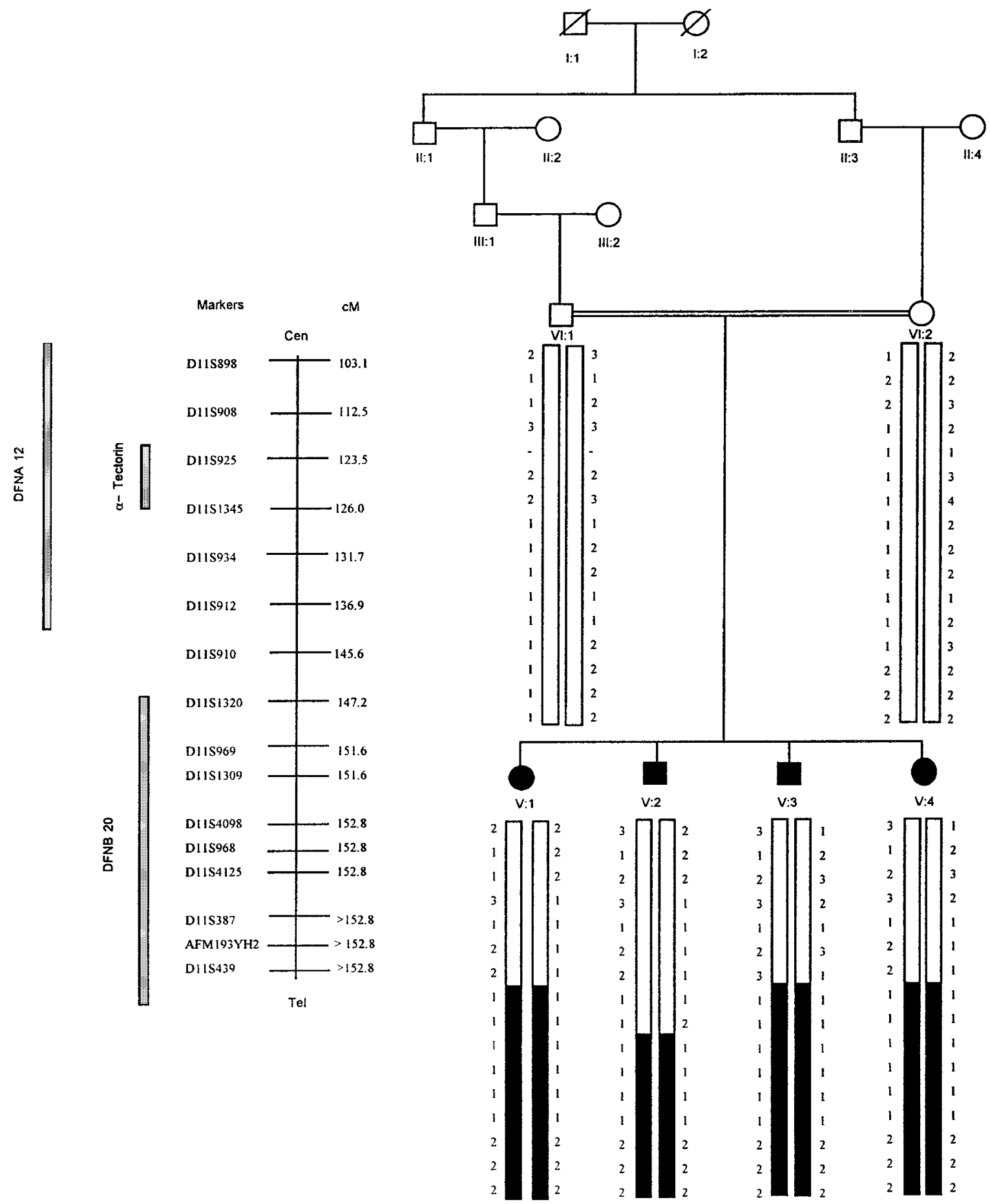

Figure 1 Pedigree of a consanguineous family with autosomal recessive non syndromal hearing loss. The homozygous intervals are represented by solid bars. The intervals containing D FNA $12,8, \alpha$-tectorin ${ }^{10}$ and D FN B 20 (this report) are also shown. Filled symbols represent affected status, open symbols represent unaffected status. D ouble lines indicate consanguineous marriages. 
reaction (PCR). Marker heterozygosity values and amplification conditions were obtained from the $\mathrm{Gen}$ ome Database (http://www.gdb.org). PCR was performed in a $10 \mu$ l reaction volume containing $40 \mathrm{ng}$ genomic DNA, 3 picomoles of each oligonucleotide primer, $1 \mathrm{U}$ of Taq DNA polymerase (Promega, UK), $10 \mathrm{~mm}$ Tris- $\mathrm{HCl}$ pH 9.0, $50 \mathrm{~mm} \mathrm{KCl}, 0.1 \%$ Triton X-100, $2 \mathrm{~mm}$ dNTPs and $\mathrm{M} \mathrm{gCl}_{2}(1.5 \mathrm{~mm})$. PCR was performed as follows: initial denaturation step $5 \mathrm{~min} / 95^{\circ} \mathrm{C}$, followed by 35 cycles of $92^{\circ} \mathrm{C} / 30 \mathrm{~s}$, annealing temperature/ $30 \mathrm{~s}, 72^{\circ} \mathrm{C} / 30 \mathrm{~s}$, with a final extension of $72^{\circ} \mathrm{C} / 5 \mathrm{~min}$. $\mathrm{PCR}$ products were electrophoresed at 800 volts in $1 \times \mathrm{TBE} / 6 \%$ acrylamide gels for $3.5 \mathrm{~h}$ on an A BI 373 DNA Sequencer. Gels were processed using the $G$ enescan analysis software Version 2.0.2 (A pplied Biosystems). G enotypes were generated using the $G$ enotyper software Version 1.1 (A pplied B iosystems).

Linkage analysis was performed using the LIPED program for two point analysis ${ }^{6}$ and $\mathrm{HOMOZ}$ for multipoint analysis. ${ }^{7} \mathrm{~A}$ fully penetrant autosomal recessive mode of inheritance was assumed with a disease gene frequency of 0.0001 . Equal recombination frequencies between males and females were used. A llele frequencies were generated from a panel of 80 unrelated, control individuals from the Pakistani community of West Yorkshire, U K.

In a single family of Pakistani origin, a region of homozygosity was observed in all four affected individuals (Figure 1). A II four affected offspring were diagnosed with hearing impairment between the ages of
3 months and 1 year following normal births. Audiological testing revealed that individuals $\mathrm{V}_{2}$ and $\mathrm{V}_{4}$ had a moderate hearing impairment (range $50-70 \mathrm{~dB}$ ), whilst individuals $V_{1}$ and $V_{3}$ had a profound hearing loss (range $>100 \mathrm{~dB}$ ). U sing two point linkage analysis, a maximum lod score was observed with marker D 11S4125 $\left(Z_{\max }=2.82 ; \theta=0\right)$ (Table 1). Multipoint analysis using the $\mathrm{HOMOZ}$ program generated a $Z_{\max }=3.3$ over an interval spanning D 11S969-qter. It was not possible to define the telomeric boundary of the interval containing DFNB20 since none of the affected individuals were recombinant with markers close to the telomere and, at present, no polymorphic markers have been reported distal of D 11S439. Currently, there are no obvious candidate genes that map to this region, $34 \mathrm{CDNA}$ markers are known to map to the interval D 11S969-qter (http://www.ncbi.nlm.nih.gov/SCIENCE 96). A locus for a dominant form of deafness (DFNA 12) maps to $11 q 22-q 24^{8}$ and recently, it has been shown that mutations in the $\alpha$-tectorin gene are responsible for deafness in these families. ${ }^{9}$ The $\alpha$-tectorin gene maps close to the marker D 11S925; ${ }^{10}$ the fact that all four affected individuals in the consanguineous Pakistani family studied are heterozygous for markers D11S1345, D11S912, D 11S910 (D11S934 was uninformative) over an interval of approximately $22 \mathrm{cM}$ distal to D 115925 effectively excludes $\alpha$-tectorin as the DFNB 20 gene.

In conclusion, we have mapped a further novel locus for non-syndromal autosomal recessive sensorineural

Table 1 Pairwise linkage analysis between the disease locus and chromosome 11q25 DNA markers. Marker order is cen-D 11S898-D 11S439-qter. M aximum lod score displayed in bold

\begin{tabular}{|c|c|c|c|c|c|c|c|}
\hline \multicolumn{8}{|c|}{ lod score at $\theta=$} \\
\hline M arker & 0.00 & 0.010 & 0.050 & 0.1 & 0.2 & 0.3 & 0.4 \\
\hline $\begin{array}{l}\text { D 11S898 } \\
\text { D 11S908 } \\
\text { D 11S925 } \\
\text { D 11S1345 }\end{array}$ & $\begin{array}{r}-18.789 \\
-2.539 \\
-15.509 \\
-13.335\end{array}$ & $\begin{array}{l}-9.006 \\
-2.067 \\
-6.511 \\
-6.863\end{array}$ & $\begin{array}{l}-2.546 \\
-0.590 \\
-1.586 \\
-2.033\end{array}$ & $\begin{array}{l}-1.499 \\
-0.341 \\
-0.855 \\
-1.228\end{array}$ & $\begin{array}{l}-0.616 \\
-0.138 \\
-0.288 \\
-0.526\end{array}$ & $\begin{array}{l}-0.238 \\
-0.056 \\
-0.077 \\
-0.207\end{array}$ & $\begin{array}{l}-0.064 \\
-0.018 \\
-0.002 \\
-0.053\end{array}$ \\
\hline $\begin{array}{l}\text { D } 11 S 934 \\
\text { D } 11 S 912 \\
\text { D } 11 S 910 \\
\text { D } 11 S 1320\end{array}$ & $\begin{array}{r}1.076 \\
-7.636 \\
-6.733 \\
1.356\end{array}$ & $\begin{array}{r}1.073 \\
-4.164 \\
-3.263 \\
1.352\end{array}$ & $\begin{array}{r}0.921 \\
-1.054 \\
-0.240 \\
1.196\end{array}$ & $\begin{array}{r}0.770 \\
-0.570 \\
0.150 \\
1.038\end{array}$ & $\begin{array}{r}0.490 \\
-0.198 \\
0.319 \\
0.728\end{array}$ & $\begin{array}{r}0.258 \\
-0.067 \\
0.231 \\
0.430\end{array}$ & $\begin{array}{r}0.090 \\
-0.019 \\
0.075 \\
0.162\end{array}$ \\
\hline $\begin{array}{l}\text { D 11S969 } \\
\text { D 11S1309 } \\
\text { D 11S4098 } \\
\text { D 11S968 }\end{array}$ & $\begin{array}{r}-3.861 \\
2.671 \\
0.363 \\
1.709\end{array}$ & $\begin{array}{r}-0.865 \\
2.665 \\
0.361 \\
1.705\end{array}$ & $\begin{array}{l}0.612 \\
2.395 \\
0.295 \\
1.523\end{array}$ & $\begin{array}{l}0.684 \\
2.111 \\
0.234 \\
1.335\end{array}$ & $\begin{array}{l}0.529 \\
1.524 \\
0.133 \\
0.957\end{array}$ & $\begin{array}{l}0.267 \\
0.922 \\
0.063 \\
0.588\end{array}$ & $\begin{array}{l}0.033 \\
0.343 \\
0.022 \\
0.250\end{array}$ \\
\hline $\begin{array}{l}\text { D } 11 S 4125 \\
\text { D 11S387 } \\
\text { A FM } 193 Y \text { H } 2 \\
\text { D } 11 S 439\end{array}$ & $\begin{array}{l}2.823 \\
1.453 \\
1.453 \\
1.453\end{array}$ & $\begin{array}{l}2.817 \\
1.450 \\
1.450 \\
1.450\end{array}$ & $\begin{array}{l}2.544 \\
1.285 \\
1.285 \\
1.285\end{array}$ & $\begin{array}{l}2.257 \\
1.116 \\
1.116 \\
1.116\end{array}$ & $\begin{array}{l}1.662 \\
0.785 \\
0.785 \\
0.785\end{array}$ & $\begin{array}{l}1.048 \\
0.467 \\
0.467 \\
0.467\end{array}$ & $\begin{array}{l}0.445 \\
0.181 \\
0.181 \\
0.181\end{array}$ \\
\hline
\end{tabular}


deafness to a region of chromosome 11q25 extending from the D 115969 to the telomere, thus demonstrating the extensive genetic heterogeneity of this condition. In previous studies, we have also observed a family segregating an unusual form of histiocytosis with associated features of joint contractures and sensorineural deafness that is linked to this region of chromosome $11 .^{5}$ It is possible that a single gene at this region is causal in both syndromal and non-syndromal forms of sensorineural deafness as it has been shown recently that different mutations in the unconventional myosin VIla gene (MYO7A) can result in either syndromic (U sher syndrome type $1 b)^{11}$ or non-syndromic forms of dominant and recessive hearing loss. $^{12,13}$ This could be explained by allelic heterogeneity or differences in genetic background. In addition, it will be important to determine the relative contribution to non-syndromal deafness of the various loci in different ethnic populations. This will facilitate the provision of accurate recurrence risk estimates in individual families.

\section{Acknowledgements}

We thank L A I-G azali, K A Brown, A H Janjua, G Karbani and $G$ Parry for their contribution to this research. Work in the authors' laboratories is supported by the Wellcome Trust, $M$ edical Research Council, Hearing Research Trust, European Community, Northern and Yorkshire R egional Health A uthority, and the West R iding M edical R esearch Trust.

\section{References}

1 Petit C: G enes responsible for human hereditary deafness: symphony of a thousand. N at $G$ enet 1996; 14: 385-391.

2 Van Camp G, Willems PJ, Smith RJH: Nonsyndromic hearing impairment: unparalleled heterogeneity. Am J H um G enet 1997; 60: 758-764.
3 D enoyelle $F$, Weil D, Maw MA et al: Prelingual deafness: high prevalence of a 30delG mutation in the connexin 26 gene. Hum Mol G enet 1997; 6: 2173-2177.

4 Zelante L, Gasparini P, Estivill X et al: Connexin26 mutations associated with the most common form of nonsyndromic neurosensory autosomal recessive deafness (DFNB1) in Mediterraneans. Hum Mol Genet 1997; 6: 1605-1609.

5 M oynihan L M , Bundey SE, H eath D et al: A utozygosity mapping, to chromosome $11 q 25$, of a rare autosomal recessive syndrome causing histiocytosis, joint contractures, and sensorineural deafness. A m J H um G enet 1998; 62: 1123-1128.

$60 \mathrm{tt} \mathrm{J}$ : E stimation of the recombination fraction in human pedigrees: efficient computation of the likelihood for human linkage studies. A m J Hum Genet 1974; 26: 773-775.

7 Kruglyak L, Daly MJ, Lander ES: Rapid multipoint linkage analysis of recessive traits in nuclear families including homozygosity mapping. A m J H um G enet 1995; 56: $519-527$

8 Verhoeven K, Van Camp G, G ovaerts PJ et al: A gene for autosomal dominant nonsyndromic hearing loss (DFNA 12) maps to chromosome 11q22-24. A m J H um Genet 1997; 60: 1168-1173.

9 Verhoeven K, Van L aer L, K irschhofer K et al: M utations in the human alpha-tectorin gene cause autosomal dominant non-syndromic hearing impairment. N at G enet 1998; 19: $60-62$.

10 Hughes DC, Legan PK, Steel KP, Richardson GP: Mapping of the alpha-tectorin gene (TECTA) to mouse chromosome 9 and human chromosome 11: a candidate for human autosomal dominant nonsyndromic deafness. G enomics 1998; 48: 46-51.

11 Weil D, Blanchard S, Kaplan J et al: Defective myosin VIIA gene responsible for U sher syndrome type $1 \mathrm{~B}$. Nature 1995; 374: 60-61.

12 Liu X-Z, Walsh J, M buru P et al: M utations in the myosin VIIA gene cause non-syndromic recessive deafness. $N$ at Genet 1997; 16: 188-193.

13 Liu X-Z, Walsh J, Tamagawa Y et al: A utosomal dominant non-syndromic deafness caused by a mutation in the myosin VIIA gene. Nat G enet 1997; 17: 268-269. 